\title{
НЕОБХОДИМОСТЬ РАЗВИТИЯ ВЕТРОЭНЕРГЕТИКИ В РЕСПУБЛИКЕ БЕЛАРУСЬ И СДЕРЖИВАЮЩИЕ ЕГО ПРЕПЯТСТВИЯ
}

\author{
Д.Ю. Хамчуков, Н.Г. Кротова*
}

\begin{abstract}
Анализируются экономические эффекты для Беларуси от замещения импорта природного газа электроэнергией ветроэнергетических установок. Описываются общие и специфические препятствия развитию ветроэнергетики в республике. Рассматривается зарубежный опыт локализации производства таких установок. Оцениваются среднесрочные перспективы их строительства и возможные механизмы стимулирования развития отрасли.
\end{abstract}

Ключевые слова: ВЭУ, замещение импорта природного газа, себестоимость выработки электроэнергии, развитие ветроэнергетики, локализация производства ветроэнергетических установок.

JEL-классификация: O14.

DOI: $10.46782 / 1818-4510-2020-4-36-51$

Материал поступил 2.07.2020 ఒ.

Еще 15-20 лет назад энергетическое будущее Беларуси выглядело безоблачным. Альтернатива импорту энергоносителей не просматривалась. Верилось, что белорусская экономика будет работать в равных экономических условиях с российской и цены на энергоносители для промышленных предприятий обеих стран будут одинаковыми. Отдельное двукратное повышение цены на природный газ в 2007 г. рассматривалось как досадное недоразумение, которое должно было быть быстро урегулировано. Сегодня Беларусь стоит перед фактом мировых цен на энергоносители. Нам следует осознать этот факт, учитывая отсутствие собственных масштабных запасов нефти и газа, и воспользоваться опытом многих стран Западной Европы.

\section{Проблема энергетической безопасности}

Трудность страновой диверсификации поставок импортного природного газа приводит к повышению цен основным поставщиком, которое реально может быть «выше мирового» уровня, вымывая из экономики валюту, истощая золотовалютные резервы и создавая угрозу устойчивости курса белорусского рубля.

Разница в стоимости природного газа для Беларуси и для российских промышленных производителей снижает ценовую конкурентоспособность белорусской продукции на российском рынке - на основном рынке сбыта для многих видов белорусских товаров.

Следующий аспект - потеря внутреннего рынка. Уже несколько лет доля белорусской продукции в белорусском розничном товарообороте снижается. При этом импорт потребительских и промежуточных товаров из стран-партнеров по ЕАЭС на наш рынок устойчиво растет. Конкурентное преимущество в ценах на энергоносители - одна из причин этого.

Большая часть импортируемого природного газа (14,5 млрд м $^{3}$ из импортированных 20,3 млрд м ${ }^{3}$ в 2018 г.) $)^{1}$ используется в Беларуси для выработки электроэнергии. Стоимость импорта природного газа в

${ }^{1}$ Энергетический баланс Республики Беларусь, 2019: стат. сборник. 2019. Минск: Национальный статистический комитет Республики Беларусь. 184 с.

\footnotetext{
* Хамчуков Дмитрий Юрьевич (hamchukov@tut.by), кандидат экономических наук (г. Минск, Беларусь);
} Кротова Нина Григорьевна (nkrotova3001@mail.ru), г. Минск, Беларусь. 
2019 г. составила 2,6 млрд долл. США (табл. 1), что сформировало $41 \%$ отрицательного сальдо внешней торговли товарами. По объективным причинам Беларусь не может заниматься замещением импорта природного газа. Но она может, используя ВИЭ², замещать электроэнергию, вырабатываемую из природного газа, тем самым укрепляя свою энергетическую безопасность и сохраняя золотовалютные резервы.

Значительная часть расходуемых на импорт газа валютных ресурсов могла бы остаться в экономике Беларуси и финансировать создание хорошо оплачиваемых рабочих мест для населения республики.

Если не предпринимать никаких усилий, то в среднесрочной перспективе (3-5 лет), по мере выхода из кризиса мировой экономики, рыночная цена на природный газ вырастет до докризисного уровня в 301 долл./ тыс. м³ (см. табл. 1). Это в 2,3 раза выше цен на газ для Беларуси в 2018 г.

Сравнивая цену импортного газа в Украине и в Беларуси за 2019 г., видим, что ей еще есть куда расти.

Вероятнее всего выгода, ранее получаемая экономикой республики от сравнительно низких цен на газ, будет утрачена, а ценовые преимущества белорусских энергоемких товаров - полностью нивелированы. Заметно снизится конкурентоспособность белорусской продукции на общем рынке ЕАЭС. Все это может привести к свертыванию в республике ряда промышленных производств и созданию дублирующих про-

2 ВИЭ - возобновляемые источники энергии. В Беларуси представлены энергией водных потоков, ветра, солнечного света, геотермальной энергией, энергией от сжигания биомассы и биогаза. изводств в соседних странах, имеющих более дешевые энергоносители.

В долгосрочной перспективе (10-15 лет) рост мировых цен на газ продолжится из-за необходимости разработки новых труднодоступных его месторождений. Следует учитывать, что разведанные запасы газа в России, при существующих объемах добычи, оцениваются в 40-50 лет ${ }^{3}$. Обустройство новых месторождений потребует строительства вахтовых поселков, трубопроводов и насосных станций. Расходы на их строительство войдут в цену импорта газа в Беларусь.

В этой ситуации разница в ценах на газ для белорусских и российских потребителей увеличится еще более, а ценовая конкурентоспособность белорусских товаров на рынке ЕАЭС снизится. Создание к 2025 г. единого рынка энергоносителей в рамках ЕАЭС не гарантирует установление для Беларуси равных цен на природный газ с российскими потребителями. Следовательно, уже сегодня необходимо начинать создавать генерирующие мощности с себестоимостью выработки электроэнергии дешевле, чем из природного газа, и не требующих импорта углеводородов.

В статье поставлена задача оценить макроэкономические эффекты для Беларуси от замещения импорта природного газа за счет строительства ВЭУ ${ }^{4}$, обозначить экономические препятствия развитию вет-

${ }^{3}$ URL: https://tass.ru/infographics/7061; URL: https:/ /www.gazeta.ru/business/2016/10/04/10229945.shtml

${ }_{4}^{4}$ ВЭУ (ветроэнергетическая установка) - устройство для преобразования кинетической энергии ветрового потока в механическую энергию вращения ротора с последующим ее преобразованием в электрическую энергию.

Таблица 1

Импорт природного газа в Беларусь и Украину

\begin{tabular}{|l|c|c|c|c|c|c|c|}
\hline \multicolumn{1}{|c|}{ Показатель } & 2013 г. & 2014 г. & 2015 г. & 2016 г. & 2017 г. & 2018 г. & 2019 г. \\
\hline $\begin{array}{l}\text { Импорт природного газа в Беларусь, } \\
\text { млн долл. США }\end{array}$ & 3369,8 & 3417,0 & 2707,2 & 2548,2 & 2774,0 & 2679,6 & 2639,0 \\
\hline $\begin{array}{l}\text { Цена импорта природного газа } \\
\text { в Беларусь, долл./тыс. }\end{array}$ & 166 & 170 & 144 & 137 & 146 & 132 & 130 \\
\hline $\begin{array}{l}\text { Цена импорта природного газа } \\
\text { в Украину, долл./тыс. м }\end{array}$ & 485 & 378 & 273,8 & 200,8 & 231,5 & 301,0 & 198,6 \\
\hline
\end{tabular}

Источник. Внешняя торговля товарами Республики Беларусь (по товарам, странам, континентам и средним ценам) в январе-декабре 2018 года: ежемесячный стат. бюллетень. Минск: Национальный статистический комитет Республики Беларусь. 121 с.; Внешняя торговля Украины, 2018: стат. сборник. 2019 Киев: Государственная служба статистики Украины; URL: https://neftegaz.ru/news/finance/515056-mnogovato-budet-stoimost-importiruemogo-gazana-ukraine-sostavila-214-6-doll-ssha-1000-m3 
роэнергетики в республике, показать актуальность в сложившейся ситуации стимулирования создания энергоисточников на основе ВИЭ.

В данной статье не рассматриваются проблемы: создания электроемких предприятий по выпуску конкурентоспособной на внешних рынках продукции, наращивания электропотребления от АЭС в ночные часы, строительства инфраструктуры по диверсификации поставок углеводородов в Беларусь, оценки бюджетной эффективности стимулирования использования ВИЭ, создания рынка электроэнергии в Беларуси. Авторы полагают, что эти темы весьма специфичны, имеют множество нюансов и могут быть полностью раскрыты в других научных статьях.

Влияние ввода Белорусской АЭС на экономику республики уже подробно проанализировано и также не рассматривается. Ввод атомной станции позволяет заместить только до 40\% природного газа, используемого для выработки электроэнергии, и не снижает до приемлемого уровня зависимость Беларуси от импорта энергоносителей, поскольку ядерное топливо Беларусь также импортирует.

\section{Ключевые показатели и источники данных, используемые в исследовании}

По данным ГПО «Белэнерго», удельный расход условного топлива на производство электроэнергии в 2019 г. составил 240,7 г.у.т./ кВт.ч 5 . В переводе на природный газ ${ }^{6}$ удельный расход - 0,2093 м м $^{3}$ кВт.ч. Цена импорта природного газа в расчетах принята равной 130 долл./ тыс. м Следовательно, стоимость природного газа, расходуемого на выработку одного 1 кВт.ч, составляет 2,72 цента США, или 27,2 тыс. долл. за 1 млн кВт.ч.

Департамент энергоэффективности Госстандарта приводит удельный расход топлива на отпуск электроэнергии на замыкающей станции в энергосистеме (Лукомльской ГРЭС) $)^{7}$ в 2018 г. на уровне

${ }^{5}$ URL: http://www.energo.by/content/deyatelnostobedineniya/proizvodstvo-elektricheskoy-energii

6 Для пересчета из условного топлива в природный газ применен коэффициент 0,869, или 869 тыс. м ${ }^{3}$ на 1 т. у. т. Коэффициент взят из Энергетического баланса Республики Беларусь.
284,1 г.у.т./кВт.ч8 . В переводе на природный газ удельный расход составлял $0,247 \mathrm{~m}^{3} /$ кВт.ч, или 3,2 цента (стоимость используемого топлива в ценах 2019 г.).

Исходя из данных ГПО «Белэнерго», каждый выработанный ветроустановкой 1 млн кВт.ч электроэнергии экономит 27,2 тыс. долл. США на покупке импортного природного газа (в ценах 2019 г.). Одна ВЭУ мощностью 1 МВт в год вырабатывает порядка 2190 млн кВт.ч (при КИУМ $0,25)^{9}$ и замещает порядка 458,4 тыс. м ${ }^{3}$ импортного природного газа на сумму 59,6 тыс. долл. США (в ценах 2019 г.).

Удельные инвестиции, расходуемые на строительство 1 МВт установленной мощности ВЭУ в Беларуси, определялись эмпирически исходя из общедоступных публикаций о реализации проектов в сфере ветроэнергетики. Для проектов в других странах значения удельных инвестиций также находились в открытых источниках, ссылки на которые указаны в тексте.

В исследовании используется показатель «срок возмещения суммы импорта ВЭУ экономией природного газа» ${ }^{10}$, который отражает, за сколько лет экономия природного газа перекроет затраты на покупку импортной ветроустановки.

Заметим, что Энергетический баланс Республики Беларусь не дает точных данных о количестве и результатах работы

${ }^{7}$ ГРЭС (государственная районная электростанция) тепловая (гидрорециркулярная) электростанция большой мощности, вырабатывающая преимущественно электрическую энергию. В Беларуси наиболее мощной является Лукомльская ГРЭС, имеющая установленную мощность 2889,5 МВт.

8 Удельный расход топлива на отпуск электро- и теплоэнергии. URL: http://energoeffekt.gov.by/programs/ forming/spravka/20190204_rashod

${ }_{9}^{9}$ КИУМ - коэффициент использования установленной мощности, характеризует соотношение фактически выработанного объема электроэнергии к максимально возможному за год. Для ветропарка в н. п. Грабники он составляет 0,28 ; для Лукомльской ГРЭС, по открытым данным, - 0,58; для Витебской ГЭС проектное значение - 0,39; для АЭС в справочной литературе указывают равным 0,8 .

${ }^{10}$ Показатель рассчитывается как отношение стоимости импортной ВЭУ (без учета стоимости ее монтажа и подключения) к сумме годовой стоимости импортного природного газа, используемого для выработки аналогичного количества электроэнергии, полученного в результате работы ВЭУ. Расход природного газа на выработку 1 кВт.ч электроэнергии взят с сайта ГПО «Белэнерго» Республики Беларусь. Потенциальный годовой объем вырабатываемой ВЭУ электроэнергии рассчитан как произведение установленной мощности, календарного времени и КИУМ. Показатель КИУМ в расчетах принят равным 0,25. 
ВЭУ в Беларуси, поскольку приводит информацию без учета малого предпринимательства. Для более полной оценки в исследовании использовались данные Государственного кадастра возобновляемых источников энергии, размещенного на официальном сайте Минприроды ${ }^{11}$.

Для расчета удельных инвестиций взяты справочные материалы, размещенные на сайте проекта по устранению барьеров развития ветроэнергетики в Республике Беларусь $^{12}$. Ряд данных о стоимости монтажа одной ВЭУ и количестве создаваемых рабочих мест на одну установку заимствован на сайте инженерно-консалтинговой компании ОДО «Энека» ${ }^{13}$, специализированной на разработке проектов в области возобновляемой энергетики. Информация о развитии ветроэнергетики в соседних странах размещена на сайте Международного агентства возобновляемой энергетики ${ }^{14}$.

Методологической основой исследования послужили работы белорусских (Падалко, Заборовский, 2006), российских (Харитонов, 2006; Елистратов, Конеченков, Шмидт, 2013) и украинских специалистов (Подгуренко, 2000) $)^{15}$.

\section{Потенщиал ветроэнергетики в Беларуси}

По итогам проведенных ранее научных исследований энергетического потенциала ВИЭ в Беларуси ${ }^{16}$ сделаны следующие выводы. Республика располагает значительными ресурсами энергии ветра. На ее территории выявлено 1840 площадок, пригодных для размещения ветроэнергетических станций (ВЭС) и ветропарков. На каждой из них мо-

11 Государственный кадастр возобновляемых источников энергии. URL: http://195.50.7.239/Charts

${ }^{12}$ URL: www.windpower.by

${ }^{13}$ URL: www.eneca.by

${ }^{14}$ URL: www.irena.org

${ }_{15}^{15}$ Кривцов В.С., Олейников А.М., Яковлев А.И. 2004. Неисчерпаемая энергия. Ветроэнергетика: учебник. Харьков: Национальный аэрокосмический университет. 400 c.

${ }_{16}$ Прокопчик Г.А. 2010. Состояние и перспективы ветроэнергетики Беларуси. Электроэнергия: от получения и распределения до эффективного использования: материалы Всероссийской научно-технической конференции. Томск: Томский политехнический университет. С. 188-190; Камлюк Г.Г. 2012. Оценка ветро- и гелиоэнергетических ресурсов территории Республики Беларусь. Географические науки в обеспечение стратегии устойчивого развития в условиях глобализаиии: материалы Международной научно-практической конференции. Минск: Издательский центр БГУ. С. 280-282. гут быть размещены несколько ветроэнергетических установок мегаваттного класса ${ }^{17}$.

Эти площадки представляют собой в основном ряды холмов высотой от 250 м над уровнем моря, где среднегодовая фоновая скорость ветра составляет более $5 \mathrm{~m} / \mathrm{c}$. Считается, что для пуска промышленной ветроустановки достаточной является скорость ветра 3,0 м/с. Подробная карта ветроэнергетического потенциала Беларуси с необходимыми пояснениями приведена в докладе Г.Г. Камлюка ${ }^{18}$.

На основании данных о распределении средней годовой фоновой скорости ветра Минприроды выбраны 22 административных района, наиболее перспективных для развития ветроэнергетики в Республике Беларусь ${ }^{19}$. Это административные территории, расположенные на Витебской, Ошмянской, Новогрудской, Оршанской, Городокской возвышенностях и на Копыльской гряде. В них, без учета городов республиканского подчинения, проживает порядка 1 млн белорусов. И численность эта ежегодно сокращается, в основном из-за отсутствия высокооплачиваемых рабочих мест. Важно, что гипотетически в 22 административных районах, если использовать природные конкурентные преимущества, могут быть созданы новые высокооплачиваемые рабочие места, а вырабатываемая из ветра электроэнергия будет востребована на внутреннем рынке.

Более подробная информация о пригодных для ветропарков площадках содержится в Государственном кадастре возобновляемых источников энергии, разработанном Минприроды ${ }^{20}$.

${ }^{17}$ Белый О., Назарова И. 2011. Ветроэнергетика Беларуси: состояние и перспективы развития. Энергосбережение - важнейшее условие инновационного развития АПК: международная научно-техническая конференция. Минск: Белорусский государственный аграрный технический университет.

${ }^{18}$ Камлюк Г.Г. 2012. Оценка ветро- и гелиоэнергетических ресурсов территории Республики Беларусь. Географические науки в обеспечение стратегии устойчивого развития в условиях глобализации: материалы Международной научно-практической конференции. Минск: Издательский центр БГУ. С. 280-282.

19 Более 20 районов определены в Беларуси для развития ветроэнергетики. URL: https://www.belta.by/economics/ view/bolee-20-rajonov-opredeleny-v-belarusi-dlja-razvitijavetroenergetiki-214281-2016/

20 URL: http://195.50.7.239/Charts 
При возведении на выявленных 1840 площадках ВЭУ установленной мощностью 2,5 МВт (каждая) их суммарная установленная мощность в Беларуси может составить $4600 \mathrm{MBT}^{21}$. Это позволит вырабатывать ежегодно порядка 10,0 млрд кВт.ч электроэнергии (при коэффициенте использования установленной мощности 0,25$)$, что составляет около $26 \%$ от потребляемой в республике электроэнергии в 2018 г. Выработка такого объема электроэнергии даст экономию в 272 млн долл. США ${ }^{22}$ на импорте природного газа (в ценах импорта газа в Беларусь в 2019 г.). При существующем технологическом уровне ВЭУ данный объем выработки будем полагать максимально возможным для республики. Однако его полное использование невозможно при существующем техническом уровне нашей энергосистемы. Но об этом речь пойдет далее.

Важен следующий вывод: у Беларуси есть существенный потенциал для замещения импорта природного газа за счет ветроэнергетики и создания на этой основе высокооплачиваемых рабочих мест. В то же время полностью заместить импорт природного газа на основе ВЭУ не удастся. Стратегия диверсификации импортных поставок СПГ через терминал в Клайпеде трудно реализуема, поскольку мы не имеем своего магистрального газопровода.

\section{Текущее состояние әнергетики на основе ВИЭ в Беларуси}

Согласно Государственному кадастру возобновляемых источников энергии, размещенному на сайте Минприроды, в Беларуси в 2019 г. действовало 125 ВЭУ с суммарной установленной мощностью 218,1 МВт и выработкой в год 709,6 млн кВт.ч, или 1,9\% от совокупного потребления в Беларуси ${ }^{23}$.

По данным Энергетического баланса Республики Беларусь, не включающего информацию от малого предпринимательства, на 1 января 2019 г. в республике установ-

21 URL: http://house.gov.by/ru/news-ru/view/8fevralja-2017-goda-v-palate-predstavitelej-sostojalsja-kruglyjstol-na-temu-ispolzovanie-prirodnogo-52266-2017/

${ }^{22}$ Сумма экономии рассчитана как произведение: выработки электроэнергии (10 млрд кВт·ч) на стоимость импорта газа для выработки 1 млн кВт.ч (27,2 тыс. долл. США).

${ }^{23}$ URL: http://195.50.7.239/Charts ленная мощность ВЭУ составляла 15 МВт, а их годовая выработка в 2018 г. достигла 99 млн кВт.ч ${ }^{24}$. Динамика ввода ветроустановок в Беларуси представлена на рис. 1.

Крупнейший на сегодня в Беларуси ветропарк мощностью 9,9 МВт (6 объединенных ВЭУ Vestas V66 по 1,65 МВт) расположен в ур. Татаришки Зельвенского района Гродненской области ${ }^{25}$. Годовая выработка электроэнергии этим парком оценивается в 23,0 млн кВт.ч. Годовое замещение природного газа составляет порядка 4,8 млн м $^{3}$ на сумму 626 тыс. долл. США (в ценах 2019 г.).

Опираясь на приведенные цифры, можно заключить: развитие промышленной ветроэнергетики в Беларуси находится на начальной стадии. Малый частный бизнес устанавливает от 1 до 10 ВЭУ в год, рассчитывая не на масштаб производства, а на прибыль за счет высоких тарифов со стороны ГПО «Белэнерго». В существующих объемах ветроэнергетика не может сколь-нибудь существенно снизить зависимость Беларуси от импорта природного газа.

\section{Стоимость ветроэнергетических установок}

Для объективного ответа на данный вопрос обратимся к ряду зарубежных и оте-

${ }^{24}$ Энергетический баланс Республики Беларусь: стат. сборник. 2019. Минск: Национальный статистический комитет Республики Беларусь. С. 61-62.

${ }^{25}$ URL: https://grodnonews.by/news/ekonomika/ gul_kak_v_metro_i_podem_s_alpinistskim_snaryazheniem_ kak_ustroen_zelvenskiy_vetropark_iznutri_.html

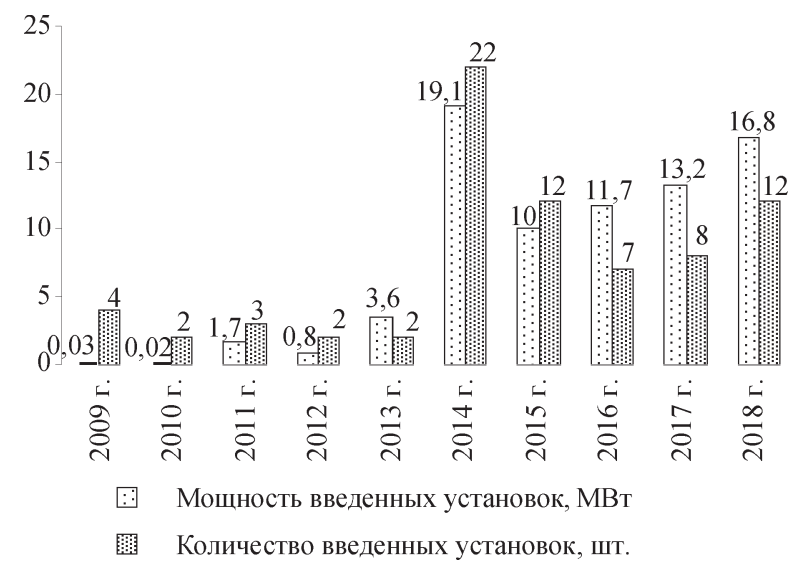

Рис. 1. Количество введенных ВЭУ и их установленная мощность

Источник. URL: windpower.by 
чественных открытых источников. По данным Международного агентства по возобновляемой энергетике (IRENA), среднемировой уровень капитальных затрат в материковой ветроэнергетике в 2017 г. составил 1,48 млн долл./MBт ${ }^{26}$.

Компания Bloomberg New Energy Finance $(\mathrm{BNEF})^{27}$ указала стоимость одного МВт установленной мощности во II полугодии 2018 г. в 1,03 млн долл. США (с учетом затрат на транспортировку). Указанная цена является общей для оффшорной и материковой энергетики и не совсем подходит для условий Беларуси.

Рассмотрим данные о стоимости ВЭУ, установленных в Беларуси.

Для ветропарка РУП «Гродноэнерго» в н. п. Грабники закуплено 5 ВЭУ установленной мощностью по 1,5 МВТ при общей себестоимости 13 млн долл. США. Следовательно, 1 МВт установленной мощности обошелся чуть более чем в 1,7 млн долл. США. Были закуплены новые ВЭУ китайской фирмы «HEAG», имеющие срок гарантийного обслуживания 3 года. Себестоимость выработки 1 кВт в 2017 г. составляла 7 коп., или 3,6 цента ${ }^{28}$. Срок окупаемости этого ветропарка, принадлежащего ГПО «Белэнерго», определен в 11 лет.

В Лиозненском районе ООО «Ветро Ватт» возвело две ВЭУ фирмы «Vensys» суммарной мощностью 6 МВт, инвестиро-

${ }^{26}$ URL: https://renen.ru/irena-has-published-new-data-onthe-economy-of-renewable-energy/; URL: https://irena.org/ publications/2018/Jan/Renewable-power-generation-costs-in-2017;

${ }^{27}$ URL: https://renen.ru/how-much-does-wind-turbine-cost/

28 URL: https://tech.onliner.by/2017/06/15/vetroparkpod-novogrudkom вав 8 млн долл. США (оценочно 1,3 млн долл. за 1 МВт) $)^{29}$.

ООО «Зилант» вложило в ветропарк в Зельвенском районе установленной мощностью 9,9 МВт 5 млн евро ${ }^{30}$. Следовательно, инвестиции на 1 МВт установленной мощности составили 560 тыс. долл. США.

Выше речь шла о новых и потому дорогих ВЭУ. Стоимость бывших в употреблении ВЭУ из Западной Европы в несколько раз ниже. Можно найти предложения о продаже установок с остаточным нормативным сроком службы в 10-12 лет при стоимости от 200 тыс. до 1 млн долл. США за 1 МВт установленной мощности. Отдельные примеры стоимости б/у ВЭУ приведены в табл. 2. Более подробная информация есть на электронной торговой площадке, на которой предлагаются бывшие в употреблении ветрогенераторы ${ }^{31}$.

Для сравнения: в Беларуси промышленные б/у ветрогенераторы Vestas V90 мощностью 3 МВт продаются фирмой ООО «Лайт Солюшнс» за 1,21 млн руб., т. е. по 403 тыс. руб. (160 тыс. долл.) за 1 МВт установленной мощности ${ }^{32}$.

Важно отметить, что стоимость самой установки (новой) в разобранном виде и ее доставки покупателю составляют порядка 70\% от суммы инвестиций в ВЭУ. Из опыта бе-

29 URL: https://www.belta.by/regions/view/vlioznenskom-rajone-nachnut-montirovat-samyj-moschnyjvetropark-v-strane-349005-2019/

30 URL: https://grodnonews.by/news/ekonomika/ gul_kak_v_metro_i_podem_s_alpinistskim_snaryazheniem_ kak_ustroen_zelvenskiy_vetropark_iznutri_.html

31 URL: https://en.wind-turbine-models.com/

32 URL: https://lso.deal.by/p64361228-vetrogeneratorpromyshlennyj-vestas.html

Таблица 2

Примеры предложений о продаже б/у ветрогенераторов в 2020 г.

\begin{tabular}{|l|l|l|l|c|}
\hline \multicolumn{1}{|c|}{$\begin{array}{c}\text { Производитель, } \\
\text { год выпуска }\end{array}$} & $\begin{array}{c}\text { Страна- } \\
\text { продавец }\end{array}$ & Модель ВЭУ & $\begin{array}{c}\text { Мощность одной } \\
\text { ВЭУ, МВт }\end{array}$ & $\begin{array}{c}\text { Стоимость одной } \\
\text { ВЭУ, тыс. евро }\end{array}$ \\
\hline Vestas (2005 г.) & Польша & Vestas V80 & 2 & 410 \\
\hline Vestas (2003 г.) & Германия & Vestas V90 & 2 & 477,5 \\
\hline Vestas (2007г.) & Германия & Vestas V90 & 2 & 2095 \\
\hline Tacke (1993 г.) & Германия & TW-500 & 0,5 & 230 \\
\hline Goldwind & Россия & Goldwind S48 & 0,75 & 360 \\
\hline Nordex (2009 г.) & Германия & Nordex N90 & 2,5 & 480 \\
\hline Vestas (2004 г.) & Германия & Vestas V52 & 0,85 & 150 \\
\hline GE Energy (2002 г.) & Германия & GE 1.5sl & 1,5 & \\
\hline
\end{tabular}

Источник. URL: https://en.wind-turbine-models.com/ 
лорусских бизнесменов, занятых проектированием и строительством ВЭУз3: строительно-монтажные работы по возведению инфраструктурных объектов оцениваются в 200 тыс. долл./МВт; еще 200 тыс. долл./МВт составляют затраты на аренду специализированных кранов для монтажа ВЭУ.

Таким образом, строительство ЛЭП и подстанции, покупка, транспортировка, монтаж бывшей в употреблении ВЭУ мегаваттной мощности с остаточным ресурсом в 10-12 лет обойдется от 600 (при стоимости самой ВЭУ 200 тыс. долл./МВт) до 1400 тыс. долл. США (при стоимости самой ВЭУ 1 млн долл./МВт).

\section{Сравнительная себестоимость выработки электроэнергии ВЭУ}

Себестоимость выработки 1 млн кВт.ч электроэнергии ВЭУ в н. п. Грабники в январе-ноябре 2015 г. была ниже на 11\%, чем себестоимость выработки электроэнергии из природного газа в среднем по энергоснабжающим организациям ГПО «Белэнерго». Даже оборудованная современным блоком ПГУ Лукомльская ГРЭС имела более высокую себестоимость выработки, чем ветропарк в н. п. Грабники.

Данное соотношение справедливо при уровне технологий ВЭУ 2005-2011 гг. и цене импорта природного газа 144 долл. США за 1 тыс. м³. В 2020 г. стоимость импорта природного газа в Беларусь снизилась до 127 долл./м³. Но и в Грабниках смонтированы не самые современные ветроустановки, уступающие по эффективности современным ВЭУ 3-мегаваттной платформы.

\section{Преимущества развития ветроэнергетики для экономики Беларуси}

Следует назвать следующие преимущества:

- низкая, относительно существующих в Беларуси ТЭЦ ${ }^{34}$, себестоимость выработки электроэнергии при ценах на природный газ выше 144 долл./тыс. м³;

33 URL: https://www.eneca.by/ru bu vetroagregati0/

${ }_{34}$ ТЭЦ (теплоэлектроцентраль) - разновидность тепловой электростанции, которая не только производит электроэнергию, но и является источником тепловой энергии в централизованных системах.
- нулевая стоимость импорта топлива, что за счет экономии природного газа позволяет перекрыть затраты валюты на импорт самой энергоустановки за 10-11 лет (в зависимости от тарифа);

- экологическая чистота (отсутствие вредных выбросов в атмосферу и в водоемы, малая площадь отчуждения пахотных земель);

- привлекательный объект для промышленного туризма, особенно в случае подъема на площадку наверху башни;

- независимость себестоимости выработки электроэнергии от резких изменений конъюнктуры мировых рынков нефти и природного газа, которые в последние годы часто происходят под влиянием операций «спекулятивного капитала»;

- строительство ВЭУ формирует спрос на цемент и арматуру белорусского производства (для создания противовеса), позволяет задействовать потенциал белорусских строительных организаций, создать в республике рабочие места для тех строителей, которые подрабатывают в России;

- ВЭУ дополняет гидроэлектростанции и солнечные электростанции, наиболее эффективно работая в зимние месяцы, когда другие виды электростанций на ВИЭ снижают выработку электроэнергии.

\section{Препятствия развитию ветроэнергетики, в том числе спещифические для Беларуси}

Занимающаяся в Беларуси ветроэнергетикой инженерно-консалтинговая компания «Энека» выделила следующие препятствия.

1.Неравномерность выдачи электроэнергии от ВЭУ в сеть, что вызвано сезонным изменением скорости ветра. Зимой ветры наиболее сильны, а летом бывает штиль. Развитие ветроэнергетики требует создания резерва компенсирующих мощностей в энергосистеме (например, газотурбинных или гидроаккумулирующих электростанций). Развитие компенсирующих мощностей также позволяет покрыть суточные пики электропотребления.

2. Сложность диспетчеризации энергосистемы при выдаче значительной мощности от ВЭУ в сеть. Выдаваемая ветроустановками мощность трудно предсказуема из- 
за погодных условий. При масштабном использовании ВЭУ требуются аккумулирующие мощности либо мощности в оперативном резерве. Возможность вовлечения в энергетический баланс вырабатываемой ВЭУ электроэнергии технологически ограничена замещением электроэнергии, вырабатываемой ГРЭС, а также имеющимися горячим и вращающимся резервами генерирующих мощностей. Данная проблема становится критической, если ВЭУ занимают 15\% и более от общей выдачи электроэнергии в сеть ${ }^{35}$. Проблема решается внедрением электронных автоматизированных систем диспетчеризации энергосистемы, созданием аккумулирующих электростанций. Для Беларуси данная проблема в ближайшее десятилетие не актуальна, поскольку использование ВИЭ в это время, скорее всего, не достигнет 15\% от выработки электроэнергии в республике.

Достижение 5\%-го объема выработки электроэнергии с использованием ВИЭ является одним из сценарных условий прогноза развития электроэнергетики в Беларуси в научно-техническом отчете ${ }^{36}$. При этом сценарном условии энергосистема Беларуси обеспечивает требуемый уровень резервирования, если консервируется только часть блоков Лукомльской ГРЭС. Кроме того, Концепцией развития электрогенерирующих мощностей и электрических сетей на период до 2030 года ${ }^{37}$ предусматривается реализация проекта по строительству пиково-резервных источников на базе ГТУ либо ГПА: Лукомльская ГРЭС - 150 МВт, Новополоцкая ТЭЦ - 100 МВт, Березовская ГРЭС - 250 МВт, ТЭЦ-5 300 МВт. Потенциально данные мощности могут использоваться для компенсации неравномерно выдаваемой мощности от ВЭУ.

3. Избыток генерирующих мощностей в Беларуси в ночное время, вызванный вводом БелАЭС, что ставит вопрос о целесообразности строительства ВЭУ. Данная проблема будет решаться постепенно, пу-

35 Разработка энергетического баланса энергосистемы Беларуси с учетом развития возобновляемой энергети$\kappa и$, в том числе ветроэнергетики: научно-технический отчет. 2019. Минск: ООО «Альфа-книга». С. 188, 197.

${ }^{36}$ Там же.

37 URL: https://minenergo.gov.by/o-koncepcii-razvitijajelektrogenerirujushhih-moshhnostej-i-jelektricheskih-setej-naperiod-do-2030-goda/ тем развития в республике электротранспорта и электрификации железной дороги, создания электроемких промышленных производств, а также стимулированием энергопотребления населением в ночные часы.

4. Отсутствие в республике сертифицированных организаций, специализированно занимающихся установкой и ремонтом ВЭУ, имеющих для этого специальную технику. Для монтажа ВЭУ приходится нанимать зарубежные организации, выплачивая им валюту и увеличивая сумму импорта на строительство ветропарков.

5. Высокая стоимость импорта новых ВЭУ, которая позволяет компенсировать стоимость импорта суммой экономии природного газа только после 22 лет эксплуатации (в ценовых условиях 2019 г.).

Имеются и специфические для Беларуси препятствия. Прежде всего это - административные барьеры ${ }^{38}$. Согласно справочному руководству по основным этапам инвестиционного проекта по ветроэнергетике, для начала проектирования ветропарка необходимо собрать 27 документов и разрешений. При реализации инвестиционного проекта по строительству ВЭУ, исходя из Постановления Совета Министров Республики Беларусь от 17 февраля 2012 г. № $156^{39}$, следует выполнить еще 58 формализованных процедур. В ходе каждой из них необходимо получить разрешение, согласование, заключение, подтверждение или другую письменную форму одобрения инвестиционного проекта по созданию ВЭУ.

Белорусский бизнес, занятый в сфере ветроэнергетики, в качестве основного препятствия быстрому развитию называет квоты на ввод ВЭУ. В соответствии с Указом Президента Республики Беларусь от 24.09 .2019 г. № 357 «О возобновляемых источниках энергии» (далее Указ № 357), создание установок по использованию ВИЭ осуществляется в пределах квот, которые отпускают электроэнергию в Белорусскую энергетическую систему с применением коэффициентов, стимулирующих использование ВИЭ в течение 10 лет с момента вво-

38 URL: https://www.windpower.by/info/manuals/

${ }^{39}$ URL: https://pravo.by/document/?guid $=3871 \& \mathrm{p} 0=$ C21200156 
да в эксплуатацию. Создание установок в пределах квот осуществляется с использованием оборудования, ранее не находившегося в эксплуатации.

ВЭУ вне квот могут строиться для целей обеспечения своей хозяйственной деятельности. Энергия сверх необходимых объемов от них может продаваться в энергосистему с применением стимулирующих коэффициентов.

Данным Указом исключается использование реновированных ВЭУ для строительства организациями вне ГПО «Белэнерго» ветропарков и отпуска электроэнергии в единую энергосистему. Единственная их сфера применения - выработка электроэнергии для собственных хозяйственных нужд владельцев ВЭУ. Таким образом, развитие ветроэнергетики негосударственной формы собственности для замещения импорта природного газа жестко ограничивается квотой. В то же время квота не распространяется на ветропарки, создаваемые организациями ГПО «Белэнерго».

В соответствии с Постановлением Министерства антимонопольного регулирования и торговли Республики Беларусь от 26 августа 2019 г. № 7040, для ВЭУ, вводимых в пределах квоты с 1.01.2020 г. по 31.12.2022 г., применяется повышающий коэффициент 1,1 в течение первых 5 лет и коэффициент 1,01 в течение последующих 5 лет.

${ }^{40}$ URL: https://pravo.by/document/?guid= $3871 \& \mathrm{p} 0=$ W21833460
Ключевое препятствие - малый размер ежегодной квоты на ввод ВЭУ, включение в которую позволяет отпускать в сеть электроэнергию с коэффициентом 1,1 к тарифу. Размер квоты в 2020 г. составляет 19,8 МВт, что соответствует 10-15 установкам большой мощности (табл. 3). В пересчете на выработку электроэнергии это равно 43,4 млн кВт.ч, что позволяет заместить импорт 9,1 млн м ${ }^{3}$ природного газа на сумму 1,18 млн долл. США. Это абсолютно недостаточно для снижения зависимости Беларуси от импорта энергоносителей.

Вся квота на ВЭУ уже зарезервирована в рамках реализации проекта международной технической помощи «Устранение барьеров для развития ветроэнергетики в Республике Беларусь». Масштабное развитие ветроэнергетики возможно только при замещении 1-2\% от импорта природного газа в год.

Есть ряд причин негативного восприятия ветроэнергетики ГПО «Белэнерго». Дело в том, что покупка ГПО «Белэнерго» электроэнергии от частных ВЭУ, построенных в пределах квоты, из-за повышающих коэффициентов по стоимости выше тарифа, по которому эту электроэнергию Белэнерго отпускает потребителям. В этом основное противоречие интересов бизнеса и ГПО «Белэнерго». Авторы полагают, что у государственной организации просто нет столько средств, чтобы субсидировать масштабное строительство ветроэнергетики в

Таблица 3

Квоты по созданию установок на 2019-2021 гг., МВт

\begin{tabular}{|c|c|c|c|}
\hline Вид возобновляемого источника энергии с использованием & 2019 & 2020 & 2021 \\
\hline Энергии биогаза & - & 6,0 & 6,0 \\
\hline Энергии ветра & 15,9 & 19.8 & - \\
\hline Энергии солнца & - & - & - \\
\hline Энергии естественного движения водных потоков & - & 7,0 & 55,0 \\
\hline Энергии древесного топлива, иных видов биомассы & - & 1,5 & 1,5 \\
\hline Тепла земли и иных источников энергии, не относящихся к невозобновляемым & - & - & 20 \\
\hline Итого & 15,9 & 34,3 & 82,5 \\
\hline
\end{tabular}

Источник. URL: https://minenergo.gov.by/ustanovleny-kvoty-na-sozdanie-ustanovok-po-ispolzovanijuvozobnovljaemyh-istochnikov-jenergii-na-2019-2021-gody/ 
Беларуси. Появление квоты, на наш взгляд, также вызвано этим фактором.

Если посмотреть глобально, то проблема заключается в отсутствии конкуренции на рынке электроэнергии: государство выступает и как регулятор, и как основной игрок этого рынка. По мнению авторов, конкурентного рынка просто нет. Нет конкуренции, следовательно нет стимула снижать стоимость электроэнергии для потребителя.

Вторым специфическим для Беларуси препятствием является длительный срок окупаемости инвестиций в ВЭУ. Новая установка мощностью 3,3 МВт с высотой мачты 105 м обойдется при покупке (на условиях самовывоза) порядка 4,5 млн долл. США. Стоимость ее монтажа и подключения - еще около 0,6 млн долл. США. Годовая выработка электроэнергии (при коэффициенте использования мощности 0,3 ) составит 8,7 млн кВт·ч, или 676,4 тыс. долл. США (по тарифу). Выплаты ГПО «Белэнерго» владельцу за электроэнергию покроют стоимость установки только через 8-9 лет. Срок окупаемости инвестиций растянется более чем на 11 лет. В описанной ситуации трудно найти частных инвесторов, желающих вкладывать в развитие современной ветроэнергетики, импортируя новые ВЭУ.

Заметим также, что стоимость приобретения Белэнерго электроэнергии от ВЭУ «привязана» к тарифу для промышленных потребителей, установленному в долларах США. В среднесрочной перспективе существует экономический риск снижения данного тарифа, что существенно увеличит срок окупаемости вложений в ВЭУ.

Длительный срок окупаемости, а также риск изменения уровня тарифа делают экономически выгодным для белорусских частных инвесторов приобретать бывшие в употреблении ВЭУ в Германии. Стоимость таких установок составляет около 300 тыс. долл. США за 1 МВт, что позволяет окупить инвестиции в ВЭУ за 34 года. Однако действие Указа № 357 ограничило использование бывших в употреблении ВЭУ только выработкой электроэнергии организациями для собственных нужд.

\section{Ближайшие перспективы развития ветроэнергетики Беларуси}

Остановимся на тех проектах/площадках, которые либо указаны в Государственном кадастре ВИЭ, либо были анонсированы государственными организациями, но не реализованы до настоящего времени. Логика этого подхода такова: если уж стимулировать развитие ВЭУ, то начинать надо с проектов, которые уже прошли техническую и экономическую проработку.

Прежде всего отметим проекты, указанные в Государственном кадастре возобновляемых источников энергии. На перечисленных в нем площадках планируется (в случае реализации анонсированных проектов) установить 29 ВЭУ суммарной мощностью 86,6 МВт и годовой выработкой электроэнергии 189,6 млн кВт.ч, что обеспечит экономию импортного природного газа на сумму 5,2 млн долл. США в год (в ценах 2019 г.). Потребность в инвестициях при использовании новых установок составит 112 млн долл. США (1,3 млн долл. на МВт). Результатом станет создание 58 новых рабочих мест (по 2 чел. на одну установку) в сельских территориях Витебской и Гродненской областей. При возведении ВЭУ будет использовано не менее 8,5 тыс. т цемента, производимого в Беларуси.

Замещение импортного природного газа в течение 25 лет работы указанных в кадастре установок (нормативный срок службы ВЭУ) составит около 992,1 млн м ${ }^{3}$, или 128,9 млн долл. США в ценах 2019 г.

Есть несколько нереализованных проектов государственных компаний.

Во-первых, строительство ПО «Беларусьнефть» ветропарков в н.п. Бурмаки (Минская область) и н. п. Лужище (Гродненская область) суммарной установленной мощностью $130 \mathrm{MBT}^{41}$ и объемом годовой выработки порядка 284 млн кВт.ч (при КИУМ 0,25). Ожидаемая экономия от работы ветропарков оценивается в 59441 тыс. м ${ }^{3}$ импортного природного газа на сумму 7,743 млн долл. США в год (в ценах 2019 г.).

Во-вторых, расширение установленной мощности ветропарка РУП «Гродноэнерго»

41 URL: https://www.belta.by/newscompany/view/ belorusneft-postroit-v-minskoj-i-grodnenskoj-oblastjahvetroparki-obschej-moschnostjju-130-mvt-175196-2015/ 
в н.п. Грабники путем строительства пяти дополнительных ВЭУ (предположительно суммарной мощностью $7,5 \mathrm{MBT})^{42}$.

Приведенные проекты (суммарно более 220 МВт) - лишь малая часть имеющегося в республике потенциала ветроэнергетики. Для его более полного использования необходимо целенаправленное стимулирование инвестиций в исследование ветров и проектирование ветропарков, создание инфраструктуры (подстанций, ЛЭП), строительство ВЭУ, a, возможно, и в частичную локализацию производства ВЭУ в Беларуси.

В ценовых условиях 2019 г. закупка новых импортных установок ВЭУ позволила бы компенсировать стоимость импорта оборудования экономией природного газа примерно за 22 года (в течение нормативного срока службы) при стоимости 1 МВт установленной мощности менее 1,3 млн долл. США.

В сложившихся ценовых условиях для сокращения срока окупаемости белорусским инвесторам целесообразно рассматривать рынок реновированных ВЭУ (б/у, прошедших капитальный ремонт). Суммарные инвестиции в строительство и подключение такой ВЭУ могут быть существенно меньше 1 млн долл. США за 1 МВТ установленной мощности.

В 2020 г. в энергосистеме Беларуси нагрузка в 20\% от пиковой существует постоянно. Время нагрузки ниже $60 \%$ от пиковой занимает около половины суток. ВЭУ могут отпускать в сеть всю свою энергию только тогда, когда они работают в базовой части формирования электрического баланса. Эта часть нагрузки существует на протяжении всего времени суток. Кроме того, в базовой части будет работать БелАЭС из-за низкого уровня маневренности мощности. Все потребности, которые не покроет БелАЭС, должны обеспечивать тепловые станции и, частично, конденсационные станции ${ }^{43}$. Таким образом, вся энергосистема (в том числе мощности на природном газе) сможет «с запасом» обес-

42 URL: https://naviny.by/article/20170616/1497 614875-kak-v-novogrudskom-rayone-delayut-dengi-iz-vozduha

43 Разработка энергетического баланса энергосистемь Беларуси с учетом развития возобновляемой энергети$\kappa и$, в том числе ветроэнергетики: научно-технический отчет. 2019. Минск: ООО «Альфа-книга». 238 с. печивать баланс электроэнергии в Беларуси. И место ВИЭ в будущем балансе электроэнергии Беларуси неочевидно.

Однако есть несколько причин, которые делают актуальным развитие генерации за счет ВИЭ и интеграции этих энергоисточников в общую энергетическую систему Беларуси. Во-первых, разведанных запасов углеводородов хватит лишь на 30-40 лет. По мере истощения запасов мировая цена природного газа будет возрастать, что сделает окончательно неконкурентоспособной цену белорусской электроемкой продукции на российском рынке. Во-вторых, развитие ВИЭ создает хорошо оплачиваемые рабочие места в сельскохозяйственных регионах, где сегодня есть проблемы с экономическим развитием. Высокие холмы и сильный ветер - это ценный природный ресурс (инвестиционный потенциал), который должен работать на экономику республики и равномерное развитие всех ее территорий.

В ближайшие годы ниша ВИЭ в балансе электроэнергии - обеспечение дневных нагрузок в общей энергосистеме (потребности крупных и средних городских поселений, крупных промышленных организаций), нагрузок в удаленных сельскохозяйственных районах, локальных нагрузок на промышленных и сельскохозяйственных предприятиях. Отдельная перспективная ниша - экспорт «зеленой» электроэнергии в страны Евросоюза. В долгосрочной перспективе (к 2030 г.) доля генерирующих мощностей на основе ВИЭ должна вырасти за счет вывода из эксплуатации мощностей на основе углеводородного топлива. Внедрение систем электрического отопления в жилом фонде также снизит потребность в работе ТЭЦ и создаст дополнительную нишу для ВИЭ. Однако для полноценной интеграции в энергосистему и обеспечение устойчивости ее работы потребуется внедрение «умных сетей» передачи электроэнергии (Smart Grid).

\section{Возможные механизмы стимулирования развития ветроэнергетики в Беларуси}

Ресурсами только самого ГПО «Белэнерго» сколь-нибудь существенного развития ветроэнергетики в Беларуси не достичь. Необходимо использовать другие источни- 
ки средств и экономические механизмы стимулирования. Важно, чтобы эти механизмы не перегружали расходную часть бюджета и не вели к резкому увеличению отрицательного внешнеторгового сальдо товарами.

Потенциально источником средств на строительство дополнительных ВЭУ может быть техническая помощь от стран ЕС. Экономически развитые страны Евросоюза заинтересованы в снижении использования углеводородного топлива для замедления темпов глобального потепления. Этот механизм работает - первый мегаватный ветряк был поставлен в Беларусь (возле д. Грабники) именно в рамках технической помощи. Основной недостаток - ничтожно малые объемы такой помощи с точки зрения достижения энергетической безопасности.

Второй возможный вариант - получение целевых кредитов от Европейского банка реконструкции и развития сроком на 1015 лет. Такое кредитование выгодно ЕС, так как стимулирует спрос на продукцию машиностроения Евросоюза. Получателями целевых кредитов могли бы выступать частные компании в Беларуси, а также ГПО «Белэнерго». Если ГПО «Белэнерго» стремится снизить себестоимость выработки электроэнергии, то, учитывая существующее законодательство, ему целесообразно реализовать проекты создания ВЭУ самостоятельно. Для экономики республики главное, чтобы стоимость экономии газа за весь период эксплуатации ВЭУ перекрывала стоимость выплат по обслуживанию кредита, а конечная цена электроэнергии для потребителей год от года снижалась (или хотя бы не повышалась).
Третьим вариантом является строительство ветропарков коммерческими организациями Беларуси за счет собственных средств. Они потенциально должны обладать высоким уровнем рентабельности и электроемкими производственными процессами. К числу таких организаций можно отнести: ОАО «Беларуськалий», ОАО «Беларуснефть», операторов мобильной сети и др. Отметим, что не всегда имеющиеся у них производственные площадки подходят для размещения ВЭУ.

В качестве варианта можно рассматривать привлечение к строительству ветропарка в Беларуси крупной международной компании, работающей в сфере ВИЭ, с последующей продажей электроэнергии ГПО «Белэнерго».

Методами стимулирования бизнеса к строительству ВЭУ, в случае дальнейшего снижения закупочного тарифа на электроэнергию, могут быть налоговые льготы, позволяющие сократить срок окупаемости инвестиций в ВЭУ. Причем, чем «моложе» устанавливаемые ВЭУ, тем больше должен быть размер льготы. Потенциально возможно также выделение кредитов Банком развития на строительство ветропарков под сниженную процентную ставку.

\section{Oпьгт развития ветроэнергетики в соседних странах}

Актуальность развития ветроэнергетики подкрепляется успешными примерами соседних стран. В первую очередь, Польши, где самая большая установленная мощность ветроэнергетики в Восточной Европе (табл. 4). Динамично развивается ветроэнергетика в Украине, где каждый год в ВЭУ инвестируют сотни миллионов долларов.

Установленная мощность промышленных ВЭУ в Беларуси и странах-соседях, МВТ

\begin{tabular}{|l|c|c|c|c|c|c|c|}
\hline \multicolumn{1}{|c|}{ Страна } & 2014 г. & 2015 г. & 2016 г. & 2017 г. & 2018 г. & 2019 г. & $\begin{array}{c}2019 \text { г. } \\
\text { к уровню 2014 г., \% }\end{array}$ \\
\hline Польша & 3834 & 5100 & 5747 & 5759 & 5766 & 5917 & 154,3 \\
\hline Эстония & 275,0 & 300,0 & 310,0 & 311,8 & 310,0 & 320,0 & 116,4 \\
\hline Украина & 514 & 514 & 526 & 553 & 621 & 1258 & 244,7 \\
\hline Латвия & 68,9 & 68,2 & 69,91 & 77,11 & 78,17 & 78,17 & 113,4 \\
\hline Литва & 288 & 436 & 509 & 518 & 533 & 546 & 189,6 \\
\hline Россия & 10,0 & 10,9 & 10,9 & 10,9 & 51,9 & 101,9 & в 10 ра3 \\
\hline Беларусь & $\mathbf{3 0 , 2}$ & $\mathbf{4 9 , 2 5}$ & $\mathbf{5 9 , 2 5}$ & $\mathbf{7 0 , 9 5}$ & $\mathbf{8 4 , 1 5}$ & $\mathbf{1 0 0 , 9 5}$ & $\mathbf{3 3 4 , 2}$ \\
\hline
\end{tabular}

Источник. URL: https://www.irena.org/wind 
Такое наращивание мощности ВЭУ укрепляет позиции страны при переговорах о цене импорта природного газа.

Заметим, что производство ВЭУ - один из самых быстрорастущих сегментов рынка энергетического оборудования в мире. Выйти на этот рынок стремятся многие страны, имеющие развитое машиностроение.

В России в г. Ульяновске в 2020 г. совместное предприятие датской фирмы «Vestas» с AO «Роснано» и фирмой «Аквилон» на площадях завода «Аэрокомпозит» начало производство из стекловолокна лопастей для ветрогенераторов «Vestas» установленной мощностью 3,45 МВт (мощность производства - 300 лопастей в год). Датская фирма «Vestas» поставляет молды (литформы), дозирующие насосы, патенты и литейное оборудование. Стекловолокно, эпоксидная смола, полиуретан и ТЭР в производстве используются российские.

Производство гондол для ВЭУ локализовано в г. Дзержинске Нижегородской области в 2018 г. В создание этого производства инвестировано 5,5 млн долл. США, при этом на предприятии занято 50 чел.

Производство башен-опор для ветрогенераторов открыто в г. Таганроге и имеет мощность 100 башен в год. Выпуском этой продукции занято 160 чел.

В 2019 г. локализация при производстве ВЭУ достигла в России 65\%. В дальнейшем АО «Роснано» и ПАО «Фортум» планируют ее нарастить за счет организации выпуска редукторов и генераторов, привлекая инвестиции фирмы «Сименс». Не менее 5\% производимых в России ВЭУ (или их частей) планируется направлять на экспорт. Развитие энергетики на основе ВЭУ, по мнению Министерства промышленности и торговли Российской Федерации, станет одним из драйверов роста и качественного развития российского машиностроения.

В рамках программы по развитию ветроэнергетики в России планируется построить к 2024 г. ВЭУ суммарной установленной мощностью 3,6 ГВт, что примерно соответствует уровню Польши. Первый промышленный ветропарк установленной мощностью 125 МВт уже построен и эксплуатируется в Республике Адыгея.
Российская Федерация обладает самыми большими в мире разведанными запасами природного газа. При этом она строит на своей территории крупные ветропарки и создает производство ВЭУ.

В Украине в г. Краматорск компанией ООО «Фурлендер Виндтехнолоджи» освоено производство ВЭУ мощностью 2,5 МВт со степенью локализации 50\%. Налажены производство башни, стеклопластиковой гондолы и обтекателя ступицы, процесс механической обработки отливки ступицы, имеется лицензия на монтаж и запуск ВЭУ. На предприятии занято 150 сотрудников, а производственная мощность составляет 100 единиц в год. За время работы компания ввела в эксплуатацию 7 ветропарков в Украине и один в Казахстане ${ }^{44}$.

Максимально возможная потребность Беларуси в ВЭУ, по числу пригодных площадок, не менее 1,8 тыс. единиц. Производство, по размерам сопоставимое с созданным в России, будет обеспечено работой как минимум на 18 лет.

Рассматривая ВЭУ по элементам, отметим следующее. В Беларуси при строительстве ВЭУ используются строительные материалы (цемент и арматура) для производства подземных противовесов. Для строительства одной установки мощностью 1,5 МВт расходуется 500 куб. м бетона. По мнению авторов, строительство около 300 ВЭУ за 5 лет потребует порядка 150 тыс. куб. м бетона, в том числе 50 тыс. т цемента.

Гипотетически на базе ОАО «Стекловолокно» могло бы быть создано производство лопастей для ВЭУ (из стекловолокна) в рамках кооперации с одним из ведущих мировых производителей ветрогенераторов, как это сделали в России.

На базе белорусских машиностроительных предприятий, имеющих опыт обработки больших металлических заготовок (ОАО «Могилевский металлургический завод» или ОАО «Кузлитмаш»), можно наладить производство башен-опор для ветрогенераторов (стальных сварных труб диаметром около 4 м).

Кроме того, при возведении ветропарков используются повышающие трансфор-

\footnotetext{
44 URL: http://fwt.com.ua/o-kompanii/
} 
маторные подстанции, на которых могут устанавливаться силовые трансформаторы белорусского производства.

Развитие ветроэнергетики - это стратегический шаг в обеспечении энергетической безопасности Беларуси. Вырабатываемая ВЭУ электроэнергия - это добавленная стоимость, создаваемая на территории республики и формирующая мультипликативный рост ВДС в других сегментах экономики.

В период кризиса и снижения цен на инвестиционные товары для Беларуси стратегически целесообразно инвестировать в создание ветропарков. После преодоления нынешнего кризиса мировые цены на газ пойдут в рост и достигнут уровня 2018 г. Республике также придется приобретать газ по мировым ценам. В 2018 г. цена природного газа для Украины была 301 долл./

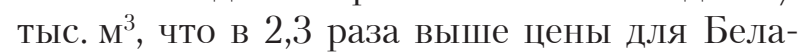
руси в этом году. Вполне вероятно, стоимость импортируемого в Беларусь природного газа, после ввода БелАЭС, не снизится, а только вырастет в сравнении с 2018 г.

По мере роста цен на газ срок «окупаемости» импорта ветроустановок экономией средств от замещения импортного природного газа сократится. Эффективность ветроэнергетики в Беларуси, которая при нынешних ценах на углеводороды «не просматривается», станет очевидной. Развивая ветроэнергетику до уровня, существующего в Польше, Беларусь сможет экономить сотни миллионов долларов на снижении импорта природного газа. Экономия средств позволит закупать технологическое оборудование для модернизации белорусских предприятий и повышения конкурентоспособности их продукции на внешних рынках. Строительство ветропарков создаст новые рабочие места в сельской местности, диверсифицирует и сделает более устойчивой к внешним шокам экономику регионов.

Стимулировать к наращиванию строительства ветропарков необходимо как частных инвесторов, так и госорганизации в сфере энергетики, для которых такая электроэнергия обходится, оценочно, дешевле на 11\% (по себестоимости, при цене газа 144 долл/ тыс. $\mathbf{M}^{3}$ ), чем выработанная из природного газа в Беларуси.

Для возведения ВЭУ в республике целесообразно создать специализированную строительную организацию, располагающую специальными колесными кранами большой грузоподъемности. Это позволит экономить валюту при монтаже ветроустановок - около 200 тыс. долл. США за 1 ВЭУ.

В ценовых условиях 2020 г. (стоимость природного газа 130,7 долл/м³) закупка импортных установок ВЭУ позволяет компенсировать стоимость импорта оборудования экономией природного газа (в течение нормативного срока службы) при стоимости 1 МВт установленной мощности менее 1 млн долл. США ${ }^{45}$.

При строительстве ветропарков в Беларуси необходимо рассматривать сценарии использования как новых ВЭУ, так и б/у ветроустановок 3-мегаваттной платформы (в странах ЕС их заменяют на ВЭУ 4-мегаваттной платформы). Такие мощные ВЭУ позволяют снижать капитальные вложения на 1 МВТ установленной мощности, сокращать срок окупаемости инфраструктуры и срок возмещения суммы импорта экономией природного газа.

В качестве задачи на период до 2025 г. авторы считают целесообразным внести в прогнозные документы целевой ориентир по достижению 5\% выработки электроэнергии (порядка 1900 млн кВт.ч в год) за счет ВЭУ (в 2018 г. - факт 0,3\%).

Для решения этой задачи к 2025 г. потребуется построить порядка 240-300 ВЭУ суммарной установленной мощностью 800 МВт (ввод по 160 МВт в год). Первыми целесообразно освоить площадки, намеченные в кадастре возобновляемых источников энергии Минприроды, поскольку их ветровой потенциал уже исследован. Строительство (при закупке новых ВЭУ) потребует

45 Одна ВЭУ мощностью 1 МВт в год вырабатывает порядка 2190 млн кВт.ч (при КИУМ 0,25) и замещает порядка 540,9 тыс. м ${ }^{3}$ импортного природного газа на сумму 59,6 тыс. долл. США (в ценах 2019 г.). Срок службы ВЭУ составляет 20-25 лет. Следовательно, за время эксплуатации установка установленной мощностью 1 МВт экономит импортный природный газ на сумму 1,2-1,5 млн долл. США. То есть позволяет гарантированно «перекрыть» стоимость импорта самой установки, если она менее 1 млн долл./МВт. 
инвестиций в размере порядка 1,25 млрд долл. США (около 250 млн долл. в год из расчета 1,56 млн долл./МВт). В случае закупки реновированных ВЭУ сумма инвестиций составит около 600 млн долл. США (из расчета стоимости покупки ВЭУ по 350 тыс. долл./ МВт). Будет создано около 500 новых рабочих мест по обслуживанию ВЭУ. Ежегодная экономия импортного природного газа составит в ценах 2019 г. 51,7 млн долл. США, а в случае роста цен до уровня 2018 г. в Украине (301 долл./тыс. м ${ }^{3}$ ) экономия достигнет 119,7 млн долл. США.

Производство ВЭУ в мире является одним из самых быстрорастущих секторов в энергетическом машиностроении. В рамках кооперации с ведущими международными производителями ветрогенераторов в Беларуси потенциально возможно освоение производства лопастей, корпусов гондол, башен-опор, а также электрооборудования (трансформаторов, генераторов, анемометров, блоков управления). В долгосрочной перспективе это позволит включиться в международную кооперацию по производству ВЭУ, сократить стоимость импорта энергетического оборудования, а также выполнять подрядные работы по ремонту ВЭУ (наращивать экспорт услуг).

Безусловно, ветроэнергетика не сможет заместить весь импорт углеводородов в республику, а природный газ - очень технологичный вид топлива для сглаживания суточных пиков в электропотреблении. Вместе с тем развитие ветроэнергетики в Беларуси позволит создать «точку роста» ВВП, независимую от колебания мировых цен на энергоносители, производящую востребованную на внутреннем рынке про- дукцию, снижающую импорт и укрепляющую экономическую безопасность республики.

В заключение отметим, что эпоха «дешевого» природного газа для Беларуси заканчивается, а разница в ценах на газ для белорусских и российских потребителей в обозримом будущем сохранится.

\section{СПИСОК ЛИТЕРАТУРЫ (REFERENCES)}

Елистратов В.В., Конеченков А.Е., Шмидт Г.А. 2013. Развитие ветроэнергетики Украины и ее состояние в России. Научно-технические ведомости Санкт-Петербургского государственного политехнического университета. № 3. C. 101-109. [Elistratov V.V., Konechenkov A.E., Shmidt G.B. 2013. Develomment of wind energy in Ukraine and its status in Russia. Nauchnotekhnicheskie vedomosti Sankt-Peterburgskogo gosudarstvennogo politekhnicheskogo universiteta. No 3. PP. 101-109. (In Russ.)]

Падалко Л.П., Заборовский А.М. 2006. Технико-экономические предпосылки развития ветроэнергетики. Энергетика и ТЭК. № 10. С. 1821. [Padalko L.P., Zaborovskiy A.M. 2006. Technical and economic prerequisites for the development of wind energy. Energetika $i$ TEK. No 10. PP. 18-21. (In Russ.)]

Подгуренко В.С. 2000. Анализ развития ветроэнергетики в Украине. Энергетика и электрификация. № 10. С. 40-51. [Podgurenko V.S. 2000. Analysis of the development of wind energy in Ukraine. Energetika i elektrifikatsiya. No 10. PP. 40-51. (In Russ.)]

Харитонов В.П. 2006. Автономные ветроэлектрические установки. Москва: Всероссийский научно-исследовательский институт электрификации сельского хозяйства. 280 c. [Kharitonov V.P. 2006. Autonomous wind power plants. Moscow: Vserossiyskiy nauchno-issledovatel'skiy institut elektrifikatsii sel'skogo khozyaystva. 280 p. (In Russ.)] 


\title{
THE NEED FOR WIND ENERGY DEVELOPMENT IN THE REPUBLIC OF BELARUS AND ITS CONSTRAINTS
}

\author{
Dmitry Hamchukov ${ }^{1}$, Nina Krotova ${ }^{1}$ \\ Authors affiliation: ${ }^{1}$ (Minsk, Belarus). \\ Corresponding author: Dmitry Hamchukov (hamchukov@tut.by).
}

ABSTRACT. The article studies the possibility of natural gas imports substitution with the energy of wind electrical plants in the Republic of Belarus and investigates its economic effects. Thus, it states both general and specific hindrances to wind energy development in the country. Foreign practices in localization of wind electrical plants production are considered. A midterm outlook for their construction is appraised; potential mechanisms to encourage further development in the industry are appreciated.

KEYWORDS: wind electrical plant, natural gas imports substitution, power cost, wind energy development, localization of wind electrical plants production.

JEL-code: O14.

DOI: $10.46782 / 1818-4510-2020-4-36-51$

Received 2.07.2020 